\title{
Profiting from the Authorized Economic Operator Paradigm in the Era of Global Value Chains: A Conceptual and Legal Analysis
}

\author{
Edward Kafeero
}

University of Dubai

E-Mail : Edward.kafeero@gmail.com

\begin{abstract}
This paper analyses the conceptual and legal development of the Authorized Economic Operator (AEO) paradigm over the past three decades. Compliance management, supply chain security and trade facilitation are found to be the underlying objectives behind AEO programs. The paper examines the dynamics of global value chains (GVCs) and concludes that AEO programs are beneficial to GVCs. The Revised Kyoto Convention, The SAFE Framework of Standards and the Trade Facilitation Agreement are identified as the basic international legal (and regulatory) framework that guides AEO programs.
\end{abstract}

Key words:1. Authorized Economic Operator; 2. Global Value Chains; 3. Supply Chain Security; 4. Trade Facilitation; 5. Customs Compliance Management.

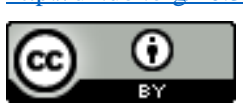

2523-6547 - Copyright: (C) 2017 The Authors. This is an open access article distributed under the terms of the Creative Commons Attribution License, which permits unrestricted use, distribution, and reproduction in any medium, provided the original author and source are credited.

Selection and Peer-review under the responsibility of the UNIVERSITY OF DUBAI - DUBAI BUSINESS SCHOOL - ICABML Conference Committee. 


\section{INTRODUCTION}

The Authorized Economic Operator (AEO) paradigm can be traced back to the mid-1990s when customs administrations in advanced economies began to put more attention on risk management and voluntary compliance mechanisms as opposed to previous control strategies. ${ }^{i}$ Over time, however, the AEO concept has evolved and it is backed by international, national and regional laws and regulations.

The past three decades have also been characterized by an increasing share of Global Value Chains (GVCs) in the overall global trade. GVCs basically refer to trade in intermediate goods and services in fragmented and internationally dispersed production processes. GVCs have become an important framework for producing of a wide variety of goods and services across the globe; and about $60 \%$ of global trade consists in trade in intermediate goods and services ${ }^{\mathrm{ii}}$

This paper seeks to:

1) Analyze the evolution of the AEO concept;

2) Show The benefits of AEO programs for both governments and the private sector in the context of GVCs; and

3) Highlight the pertinent international legal provisions, standards and tools necessary for implementing AEO programs.

\section{EVOLUTION OF THE AEO CONCEPT}

\subsection{The first phase - $A E O$ as a model and tool for voluntary compliance}

The idea that Customs need to partner with the private sector in such ways as to increase voluntary compliance with customs laws gained currency in the 1990s. A theory of customs compliance management based, so to say on "carrots and sticks" had taken root. In 1998, for instance, David Widdowson published an article with the title "Managing Compliance: More Carrot, Less Stick". iii The gist of this school of thought is the imperative to make good use risk management to strike an appropriate balance between trade facilitation and regulatory control.

Consequently, many customs administrations especially in developed economies designed programs to facilitate compliant traders. And the first programs were intended to cover a wide variety of Customs risks and involve a broad range of international trade stakeholders such as manufacturers, exporters, logistics, freight forwarders, importers, etc. Sweden, for instance, adopted two "clearance regimes aligned with compliance management through its two accreditation schemes: Stairway, which asses supply chain quality; and StairSec, supply chain security. Both schemes established a clear relationship between the degree of risk that a trader poses and the degree of trade facilitation that this trader can enjoy". iv

From a legal perspective, the above-mentioned AEO related developments made their way into the Revised Kyoto Convention (RKC) ${ }^{v}$. Transitional Standard 3.32 on special procedures for authorized persons reads:

"For authorized persons who meet criteria specified by the Customs, including having an appropriate record of compliance with Customs requirements and a satisfactory system for managing their commercial records, the Customs shall provide for:

- release of the goods on the provision of the minimum information necessary to identify the goods and permit the subsequent completion of the final Goods declaration;

- clearance of the goods at the declarant's premises or another place authorized by the Customs;

- and, in addition, to the extent possible, other special procedures such as:

- allowing a single Goods declaration for all imports or exports in a given period where goods are imported or exported frequently by the same person;

2523-6547 - Copyright: (C) 2017 The Authors. This is an open access article distributed under the terms of the Creative Commons Attribution License, which permits unrestricted use, distribution, and reproduction in any medium, provided the original author and source are credited. 
- use of the authorized persons' commercial records to self-assess their duty and tax liability and, where appropriate, to ensure compliance with other Customs requirements;

- allowing the lodgment of the Goods declaration by means of an entry in the records of the authorized person to be supported subsequently by a supplementary Goods declaration."

That international standard contains, so to say, the DNA of all the past, current and future AEO programs. It is, in some sense, constitutional in nature. Note that subsequent AEO-related instruments and tools of the World Customs Organization (WCO) are rooted in that this Standard. Also, Article 7 of the World Trade Organization's (WTO) Agreement on Trade Facilitation (commonly referred to as 'TFA') which regulates trade facilitation measures for Authorized Operators in rooted Standard 3.32 of the Revised Kyoto Convention.

\subsection{The second phase - Dominance of the 'supply chain security' aspect; and the role of the 'SAFE Framework $^{\text {,vi }}$}

After the 9/11 terrorist attacks, analysts and policy makers realized how international modes of transport could be exploited by terrorists to damage economies and social well-being of nations. This triggered the enactment of different laws aimed at securing the international supply chain. And within the international Customs community, a 'customs security' objective was added to the pre-9/11 customs priorities such as revenue collection, conventional anti-smuggling, and trade facilitation. ${ }^{\text {vii }}$

The principle of 'pushing the borders outwards' was key to the various supply chain security programs initiated in the aftermath of 9/11. This principle basically means that Customs administrations need to shift their focus from the traditional 'place of import' to include the entire trade supply chain that covers the movement of goods from origin to destination. ${ }^{\text {viii }}$ Consequently, customs controls should take place closer to the point of export. ${ }^{\text {ix }}$ And finally, closer cooperation between countries and all government bodies and the private sector involved in the various supply chain security initiatives becomes indispensable. ${ }^{\mathrm{x}}$

Among other supply chain security initiatives, the United States of America launched the 'Customs-Trade Partnership against Terrorism' (C-TPAT) in November 2001 as a joint effort between the United States government and businesses involved in importing goods into the US. Any company that wants to join the program must be able to apply specified security measures along their supply chain. And upon validation by US Customs, the company is entitled to certain benefits such as reduced inspections and faster clearance times. "Today, more than 11,400 certified partners spanning the gamut of the trade community, have been accepted into the program. The partners include U.S. importers/exporters, U.S./Canada highway carriers; U.S./Mexico highway carriers; rail and sea carriers; licensed U.S. Customs brokers; U.S. marine port authority/terminal operators; U.S. freight consolidators; ocean transportation intermediaries and non-operating common carriers; Mexican and Canadian manufacturers; and Mexican long-haul carriers, all of whom account for over 52 percent (by value) of cargo imported into the U.S." xi

Apart from the United States, many other countries and regions came up with different initiatives to strengthen supply chain security. For instance, the European Union (EU) introduced the concept of Authorized Economic Operator (AEO), which was later included in WCO's SAFE Framework. ${ }^{\text {xii }}$

WCO Members adopted the SAFE Framework in June 2005. This international customs instrument was built on principles already contained in the RKC and on earlier supply chain security initiatives from the USA and other regions. It consolidated and internationalized modern supply chain security standards that focus on end-to-end management of goods moving across borders. These standards are meant to enhance supply chain security and at the same time facilitate trade. They represent a balanced customs supply chain security model is not just focusing on 'security at all costs'. After all, as some scholars have observed ${ }^{\text {xiii }}$, an exaggerated quest for security may end up causing more harm than good.

The 2007 version of the SAFE Framework incorporated detailed provisions on the conditions and requirements for Customs and AEOs, which were initially developed in a separate document. This addition was driven by the perception that both Customs and its business partners would benefit from having all SAFE and AEO provisions readily available in a single comprehensive instrument. The 2012 version then included new parts concerning Coordinated Border Management (CBM) plus Trade Continuity and Resumption, as well as Annex I for 
definitions. And the current 2015 version of the SAFE Framework adds a new Pillar 3 called: 'Customs-to-other Government and Inter-Government Agencies' which is meant to foster closer cooperation between Customs and other government agencies thereby ensuring an efficient and effective government response to the challenges of supply chain security. ${ }^{\text {iv }}$

The SAFE Framework revolves around four core elements namely:

- Harmonization of advance cargo information requirements on inbound, outbound and transit shipments;

- Commitment to use a consistent risk management approach to address security threats;

- Requirement of the sending nation's Customs administration to perform (at reasonable request of the receiving nation, and based on a comparable risk targeting methodology) an outbound inspection on high-risk cargo and/or transport conveyances, preferably using non-intrusive equipment such as X-ray machines and radiation detectors; and

- $\quad$ Security-oriented AEO programs. These programs are designed to give benefits such as: fewer physical and document-based controls; priority treatment of consignment if selected for control; free choice of the place of controls; easier admittance to customs simplifications; reduced data set for summary declaration; fewer controls during clearance and external audits; prior notification of imminent inspections; improved relations with Customs; increased recognition as a secure and safe business partner; and eventual worldwide mutual recognition. ${ }^{\mathrm{xv}}$

\subsection{The third phase - AEO as a smarter customs control model and a trade facilitation tool}

The emphasis on the security dimension of AEOs created two things. First, it triggered the drive for governments to create AEO programs and for companies to join them to achieve the various benefits elaborated above. Second, and slightly contrary to the 'original vision' of the AEO paradigm, the emphasis on security somewhat marginalized other possible benefits. For instance, "when AEO was introduced in the EU, a common dominator level of harmonization in relation to both requirements and benefits had to be found. In practice, this meant that many countries had to remove existing benefits and individual solutions because of the introduction of a common model throughout the Customs Union. This has had a clear negative impact on the available benefit packages, especially in regions and countries where trade facilitation has generally been prioritized and where, for example, the release of goods is already fast." $x v i$

However, we are beginning to see the AEO concept become a complete 'management system'. It is becoming a smarter management system using less intrusive controls that produces efficient and transparent processes. It is a management system that involves many stakeholders in the supply. In other words, it need not be limited to Customs and traders. Other relevant government agencies can get involved. Obviously, the benefits for the stakeholders need to be worth the cost involved. The AEO program in the United Arab Emirates is one of such smarter 'third generation' (G3) type of Authorized Economic Operators.

\section{UNDERSTANDING THE DYNAMICS OF GLOBAL VALUE CHAINS}

GVCs are all about globalization; but a different kind of globalization from what the world had seen before. Richard Baldwin ${ }^{x v i i}$ uses the phrase "Globalization's Second Unbundling" to refer to the reality of GVCs. This is because GVCs involve international separation of factories. And the separation of factories (also referred to as offshoring) increased from around the 1990s because better, cheaper and efficient communications made it possible to coordinate complex activities at a distance.

Companies offshore because it is profitable to do so. And it is profitable because mainly because of three reasons. First, the wage difference between industrialized countries (where the companies are normally headquartered) and the less industrialized countries where the factories are offshored. Secondly, information technology is making the coordination work cheaper. Thirdly, developments in international transport systems have also made trade in intermediate products quicker and reliable. Fourthly, and as will be elaborated further, more efficient customs management systems have made GVCs to flourish as they enable quick clearance traded intermediate products.

Just as an example of the recent figures on GVCs, in 2011 the share of value added in Eurozone exports stood at $21.2 \%$ of the total exports. There is an increasing trend in the share of foreign value added in exports in the

2523-6547 - Copyright: (C) 2017 The Authors. This is an open access article distributed under the terms of the Creative Commons Attribution License, which permits unrestricted use, distribution, and reproduction in any medium, provided the original author and source are credited. 
Eurozone, and in the world's other major economic blocks. In addition, the bilateral intra-Eurozone value added flows make show that Germany plays a core role in such production linkages, notably with France. And manufacturing retains a dominant role in most of these linkages. ${ }^{\text {xiii }}$

GVCs have changed the patterns of industrial competitiveness in such a way that now the industrial networks rather than national boundaries matter a lot. This, however, is not to meant to disregard the fact that proximity to industrialized countries still plays a big role. ${ }^{\text {xix }}$ Proximity to industrialized countries still matters mainly because the cost of moving people (experts and managers) is still high as their salaries and bonuses increase the further from home they travel. That is why, for instance, German manufacturers would find it easier to offshore to Eastern European countries than to Argentina or South Africa.

What is discussed on GVCs above has implications, namely that, today's industrial competitiveness is largely determined by offshoring companies. That, for instance, implies that instead of building a whole supply chain domestically to become competitive internationally, developing nations might find it more reasonable to join international production arrangements to become competitive and industrialize by getting more good jobs inside global and regional value chains. ${ }^{\mathrm{xx}}$

\section{TRADE FACILITATION IN THE CONTEXT OF GVCS: THE CENTRALITY OF AEO PROGRAMS}

The term 'trade facilitation' is the main link between AEO programs and GVCs. And trade facilitation means 'the simplification and harmonization of international trade procedures; where trade procedures are the activities, practices, and formalities involved in collecting, presenting, communicating and processing data required for the movement of goods in international trade'. ${ }^{\mathrm{xi}}$ There are obviously other factors that facilitate or impede participation in GVCs such as: the quality of physical infrastructure like roads, railways, ports, etc.; the diversity and capacities of firms; the suitability/unsuitability of government policies; tariff and non-tariff measures; as well as logistics. But this paper uses trade facilitation as understood in the above WTO context.

In July 2014, the GVC Report submitted to the G20 Trade Ministers Meeting in Sydney highlighted, among other things, that G20 governments needed implement and ratify the WTO Agreement on Trade Facilitation as quickly as possible, and consider implementing TF measures - such as streamlining customs procedures - even before the ratification process is finalized. In addition, developed countries were asked to provide support to developing countries as they make trade facilitation commitments that require additional technical assistance.

\subsection{The TFA}

The TFA provisions are intended to expedite the movement, release and clearance of goods, including goods in transit. This is particularly vivid in Section I of the Agreement which clarifies and improves articles V, VIII and $\mathrm{X}$ of the GATT 1994 that deal with freedom of transit, fees and formalities connected with importation/exportation, and publication and administration of trade regulations respectively. It also includes provisions on Customs cooperation.

In addition, the TFA includes Section II which deals with special and differential treatment (SDT) of developing and least-developed countries (LDCs). The section essentially allows developing and less-developed countries to implement individual provisions of the Agreement and to identify provisions that they will only be able to implement upon the receipt of technical assistance and support for capacity building. ${ }^{x i i}$

Section III of the TFA then includes provisions that establish a permanent committee on trade facilitation at the WTO $^{\text {xiii }}$ and require members to have a national committee to facilitate domestic coordination and implementation of the provisions of the Agreement ${ }^{\mathrm{xxiv}}$. It ends with Article 24 which includes final provisions.

The TFA received much support from both national governments and international organizations such as the WCO, OECD, World Bank, IMF etc. In addition, the 'Trade Facilitation Agreement Facility' (TFAF) was created to support developing and least-developed country Members to help ensure that they receive the assistance needed to achieve full benefits of the TFA.

2523-6547 - Copyright: (C) 2017 The Authors. This is an open access article distributed under the terms of the Creative Commons Attribution License, which permits unrestricted use, distribution, and reproduction in any medium, provided the original author and source are credited. 


\subsection{The RKC-TFA complementarity}

The RKC and TFA are two international agreements that complement each other. They are both supposed to contribute to the simplification, harmonization, automation of the procedures applied to international trade, particularly the requirements and formalities related to importation and exportation with a view to further expediting the movement, release and clearance of goods, including goods in transit. The TFA, however, is different from that of the RKC mainly because unlike the WCO, the WTO has an in-built and largely effective WTO dispute settlement system which facilitates its implementation.

In addition, the TFA provisions are designed in a relatively clearer and precise form than RKC's standards, transitional standards and recommended practice. The precision in FTA provisions can obviously contribute to legal certainty and predictability, thereby providing a more reliable framework of action about trade facilitation from WTO members.

The political influence of the WTO under whose auspices the TFA was developed, adopted and implemented is also very important. The WTO provides common rules for 164 Members (as of 29 July 2016). Besides, since the TFA managed to be the first 'offspring' of the once supposed 'barren' Doha Round 'it enjoys every one's attention'. All this shows the importance of the TFA, which is expected to contribute considerably to global trade facilitation.

The RKC and TFA offer the current best international legal provisions and practical standards and best practices for trade facilitation which are key to developing global value chains. And as such, the GVCs and trade facilitation paradigms are mutually supportive. In other words, GVCs have much to gain from trade facilitation. Hence any efficient and beneficial AEO programs are also beneficial to GVCs.

\section{CONCLUSIONS}

Trade facilitation is the 'game changer' in the conception, designing and implementation of AEO programs in the recent past. Since the signing of the TFA during the 2013 Bali Ministerial Conference, through its entry into force on $22^{\text {nd }}$ February 2017, there are many promising developments in the AEO programs. The AEO model is progressively expanding from compliance management and supply chain security models to a multifaceted management system that not restrict itself to Customs-business partnerships but also involves other relevant border agencies like immigration, police, tax agencies, etc. This trend should continue.

Policy makers, the private sector and the at national, regional and international levels continue to design AEO programs that encourage voluntary compliance, offer tangible benefits to both small and big companies, that are holistic in nature, and facilitate the trade supply chain. In addition, the AEO programs are strengthened by monitoring and evaluation mechanisms which increases the transparency and positively contributes to their sustainability. That is also a good trend.

Developments in information and other technologies are also being studies and gradually employed in the management of AEO programs. Responsible use of information technologies such as GPS, GALILEO, GLONASS, Indian Regional Navigational Satellite System (IRNSS), X-ray and Gamma-ray radiography, mechanical and electrical seals, etc. should certainly be well integrated in AEO programs in a manner that is less intrusive and which facilitates trade.

2523-6547 - Copyright: (C) 2017 The Authors. This is an open access article distributed under the terms of the Creative Commons Attribution License, which permits unrestricted use, distribution, and reproduction in any medium, provided the original author and source are credited. 


\section{Reference List}

Amador J. and di Mauro F. (Eds.), The age of global value chains: Maps and policy issues, London, CEPR Press, 2015.

Bowman G. W., 'Thinking outside the border: Homeland security and the forward deployment of the US border', Houston Law Review, vol. 44 no. 2, 2007, pp.189-251.

Deibel T. L., Foreign Affairs Strategy - Logic for American Statecraft, New York, Cambridge University Press, 2007.

Ireland R., 'The WCO SAFE Framework of Standards: Avoiding excess in global supply chain security policy', Global Trade and Customs Journal vol. 4, no. 11/12, 2009. Also available at: <http://www.wcoomd.org/en/topics/research/activities-andprogrammes/ /media/44CC67F66E7C48FC9834F3504F9D7C19.ashx>.

Ireland R., The customs supply chain security paradigm and 9/11: Ten years on and beyond, WCO Research Paper No. 18, 2011; available at: < http://www.wcoomd.org/en/topics/research/activities-andprogrammes/ /media/2498A32A98FB4A0792EE4D66C8D68383.ashx >.

McLinden G., Fanta G., Widdowson D., Doyle T, Border management modernization, Washington DC. World Bank Publishing.

Mikuriya K., 'Supply chain security: the custom community's response', World Customs Journal, vol. 1, no. 2, 2007, pp. 51-59.

OECD, Interconnected economies: Benefiting from global value chains, 2009; Available at: http://www.oecd.org/sti/ind/interconnected-economies-GVCs-synthesis.pdf

OECD, WTO and WBG, Global Value Chains: Challenges, Opportunities, and Implications for Policy. This a report which was prepared for submission to the G20 Trade Ministers Meeting in Sydney, Australia, $19^{\text {th }}$ July 2014.

UNCTAD, World Investment Report 2013, New York and Geneva, 2013.

US Government Accountability Office, Supply Chain Security - Challenges to Scanning 100\% of US-bound Cargo Containers, GAO-08-533T, 2008.

WCO, International convention on the harmonization and simplification of customs procedures, 1999; available at: $<$ http://www.wcoomd.org/en/topics/facilitation/instrument-andtools/conventions/pf_revised_kyoto_conv/kyoto_new.aspx $>$.

WCO, SAFE Framework of Standards to Secure and Facilitate Global Trade, 2015; available at: $<$ http://www.wcoomd.org/en/topics/facilitation/instrument-andtools/tools/ /media/2B9F7D493314432BA42BC8498D3B73CB.ashx >.

Wolffgang H. M. \& Kafeero E., 'Old wine in new skins: analysis of the Trade Facilitation Agreement vis-à-vis the Revised Kyoto Convention’, World Customs Journal, vol. 8, no. 2, 2014, pp. 27-37.

WTO, Trade Facilitation Agreement, WT/L/931, 2014; available at: <https://www.wto.org/english/tratop_e/tradfa_e/tradfa_e.htm>.

2523-6547 - Copyright: (C) 2017 The Authors. This is an open access article distributed under the terms of the Creative Commons Attribution License, which permits unrestricted use, distribution, and reproduction in any medium, provided the original author and source are credited. 
2523-6547 - Copyright: (C) 2017 The Authors. This is an open access article distributed under the terms of the Creative Commons Attribution License, which permits unrestricted use, distribution, and reproduction in any medium, provided the original author and source are credited. 
' See L. Karlsson, 'Back to the future of Customs: A new AEO paradigm will transform the global supply chain for the better', World Customs Journal, vol. 11, no. 1, 2017, pp. 23-33, p.24.

ii J. Amador and F. di Mauro (Eds.), The age of global value chains: Maps and policy issues, London, CEPR Press, 2015, p. 15.

iii See D. Widdowson, 'Managing risk in the customs context', in L. De Wulf \& J.B. Sokol, Customs Modernization Handbook, World Bank 2005, pp. 91-99, p. 99.; Also read: G. McLinden, G. Fanta, D. Widdowson, T. Doyle, Border management modernization, Washington DC. World Bank Publishing. iv L. Karlsson, Op. Cit., p. 26.

" The Revised Kyoto Convention is officially known as the "International Convention on the Simplification and Harmonization of Customs procedures", which originally came into force in 1974, but was later updated to meet the current demands of governments and international trade. The WCO Council adopted the RKC in June 1999 as the blueprint for modern and efficient Customs procedures in the 21st century. The RKC entered into force on February 3, 2006.

vi "SAFE Framework" is the short name of WCO's SAFE Framework of Standards to Secure and Facilitate Global Trade.

vii See R. Ireland, 'The customs supply chain security paradigm and 9/11' p. 3.

viii K. Mikuriya, 'Supply chain security: the custom community's response', World Customs Journal, vol. 1, no. 2, 2007, pp. 51-59, p.51.

ix See G. W. Bowman, 'Thinking outside the border: Homeland security and the forward deployment of the US border', Houston Law Review, vol. 44 no. 2, 2007, pp.189-251.

x See F. Altemöller, 'Towards an international regime of supply chain security: an international relations perspective', World Customs Journal, vol. 5, no. 2, 2011, pp. 21-33.

xi See https://www.cbp.gov/border-security/ports-entry/cargo-security/ctpa - accessed on 14 ${ }^{\text {th }}$ October 2017.

xii See H.-M. Wolffgang \& T. Ovie, 'Emerging issues in European customs law' World Customs Journal, vol. 2, no. 1, 2008, pp. 1-16, p. 12.

xiii For instance, Deibel wrote that policymakers should seek "not to counter all conceivable threats to the maximum degree, lest they do damage to other interests in the processes (e.g., hurting prosperity by overspending to protect physical security) or generate counteractions that will leave interests less protected or advanced than when they began". See T. L. Deibel, Foreign Affairs Strategy - Logic for American Statecraft, New York, Cambridge University Press, 2007, p. 147.

xiv See K. Mikuriya, in WCO's 'SAFE Framework of Standards to Secure and Facilitate Global Trade', 2015 Version, p. 1.

xv See WCO 2015, SAFE Framework, Section 1, no. 2.

xvi L. Karlsson, Op. Cit., p. 27; Also, see Widdowson et al., 'Review of accredited operator schemes: an Australian study', World Customs Journal, vol. 8, no. 1, 2014, pp. 17-34.

xvii See R. Baldwin, The Great Convergence: Information Technology and the New Globalization, The Belknap Press of the Harvard University Press, Cambridge, 2016, pp.5-13.

xviii See J. Amador, R. Cappariello and R. Stehrer, 'Foreign value added in Eurozone exports', in J. Amador, and F. di Mauro (Eds.) 2015, The age of global value chains: Maps and policy issues, CEPR Press, London, 2015 p. 26 [emphasis added].

xix See G. Gereffi \& K. Fernandez-Stark; 'Global Value Chains Analysis: A primer', Center for Globalization, Governance \& Competitiveness, Duke University 2016, pp. 1-34, p..10.

${ }^{x x}$ See R. Baldwin, Op. cit., p.14.

xxi See http://gtad.wto.org/trta subcategory.aspx?cat=33121, accessed on $11^{\text {th }}$ October 2017.

xxii See TFA, Art. 13.

xxiii TFA, Art. 23:1.

xxiv TFA, Art. 23:2.

2523-6547 - Copyright: (C) 2017 The Authors. This is an open access article distributed under the terms of the Creative Commons Attribution License, which permits unrestricted use, distribution, and reproduction in any medium, provided the original author and source are credited. 
2523-6547 - Copyright: (C) 2017 The Authors. This is an open access article distributed under the terms of the Creative Commons Attribution License, which permits unrestricted use, distribution, and reproduction in any medium, provided the original author and source are credited. 